\title{
Unfinished Symphonies
}

Citation for published version (APA):

Peters, P. (2019). Unfinished Symphonies. Datawyse / Universitaire Pers Maastricht. https://doi.org/10.26481/spe.20190329pp

Document status and date:

Published: 01/01/2019

DOI:

10.26481/spe.20190329pp

Document Version:

Publisher's PDF, also known as Version of record

\section{Please check the document version of this publication:}

- A submitted manuscript is the version of the article upon submission and before peer-review. There can be important differences between the submitted version and the official published version of record.

People interested in the research are advised to contact the author for the final version of the publication, or visit the DOI to the publisher's website.

- The final author version and the galley proof are versions of the publication after peer review.

- The final published version features the final layout of the paper including the volume, issue and page numbers.

Link to publication

\footnotetext{
General rights rights.

- You may freely distribute the URL identifying the publication in the public portal. please follow below link for the End User Agreement:

www.umlib.nl/taverne-license

Take down policy

If you believe that this document breaches copyright please contact us at:

repository@maastrichtuniversity.nl

providing details and we will investigate your claim.
}

Copyright and moral rights for the publications made accessible in the public portal are retained by the authors and/or other copyright owners and it is a condition of accessing publications that users recognise and abide by the legal requirements associated with these

- Users may download and print one copy of any publication from the public portal for the purpose of private study or research.

- You may not further distribute the material or use it for any profit-making activity or commercial gain

If the publication is distributed under the terms of Article $25 \mathrm{fa}$ of the Dutch Copyright Act, indicated by the "Taverne" license above, 


\section{Maastricht University}

Inaugurele rede

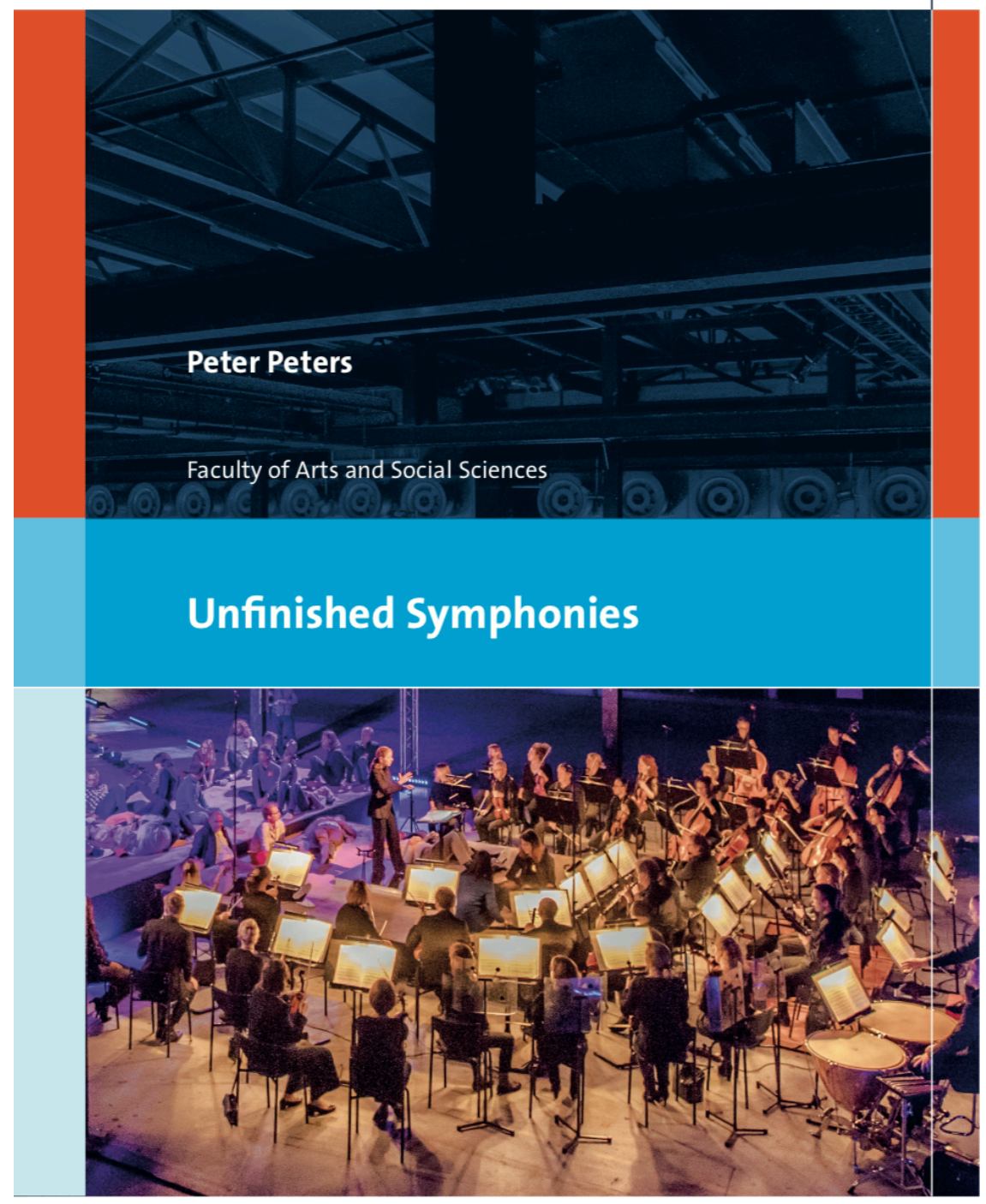





\section{Unfinished Symphonies}




\section{Colophon}

Design and print: Datawyse || Universitaire Pers Maastricht

Cover: The i-Classics 'Music and Technology' concert by philharmonie zuidnederland, Technologiegezelschap CREW, and sound artist Christoph De Boeck in the Klokgebouw Strijp-S in Eindhoven, November 2017. Photo: Jean-Pierre Geussens.

ISBN: 9789463802918

NUR: 665

All rights reserved. No part of this publication may be reproduced, modified, stored in a retrieval system or made public without the prior written permission of the author or publisher. 


\section{Unfinished Symphonies}

Rede

Uitgesproken bij de aanvaarding van het ambt van bijzonder hoogleraar Innovatie van Klassieke Muziek aan de Faculteit der Cultuur- en Maatschappijwetenschappen van de Universiteit Maastricht

op vrijdag 29 maart 2019

door

dr. Peter Peters 

Mevrouw de Rector,

dames en heren,

ladies and gentlemen,

Here we are. Listening to music in a university auditorium that is dedicated to the spoken and written word. ${ }^{1}$ The sounds changed this space and how we experience it, what we expect of what will come. Some of you have continued your conversation, politely turning down the volume. Others stopped talking, to pay attention to the music. Entering the auditorium, you may have wondered what was going on and how you should react to the situation. Through their playing, Axel Dewulf and Frank Nelissen, percussionists of the South Netherlands Philharmonic, have turned you into a music audience. Some of you may have classified the sounds as a style called Minimal music. There are those among you who will have recognized the composer, Steve Reich, or who happen to know the piece: Nagoya Marimbas, composed in 1994.

In my lecture, I will take this situation as a starting point to reflect on what it means to make music, to perform and listen to it, to study and rehearse it, and to give value to it. I will do so in the context of Western art music, often called classical music. If we follow current debates in and about this art practice, there is a sense of crisis. The value of the canon of musical works of the past is no longer self-evident. Audiences are aging, and young people hesitate to join the rituals of the classical music concert. Orchestra leaders emphasize the need to make their organisations relevant again in today's societies. In policy papers, words

\footnotetext{
${ }^{1}$ I would like to thank Ruth Benschop, Maarten Doorman, René Gabriëls, Bernike Pasveer, and Neil Smith for their valuable comments on an earlier version of this text. I could not have written it without the support and the research projects of the researchers in the Maastricht Centre for the Innovation of Classical Music: Imogen Eve (Music in the Making with Artful Participation), Denise Petzold (Resisting Closure: A Museum Studies Approach to Performing the Canonic Heritage of Symphonic Music), Neil Smith (Placing the Orchestra: Future Sites of Classical Music Performance), Veerle Spronck (Listen Closely: Innovating Participation in Symphonic Music), and Ties van de Werff (Experiments in Participation).
} 
such as innovation, participation, and diversity frame both the problems and the directions in which solutions should be found.

As you can see, it is easy to move from something as concrete as the sound of two marimbas to broad generalizations about a crisis in classical music. But before we can say anything meaningful about this crisis, we need to take a closer look at what just happened. Following the musicianresearcher Christopher Small, we have been musicking. ${ }^{2}$ Turning the noun music into a verb, Small claims that music is not a thing, but an activity. The meaning of the musical performance we just heard is created in a context to which not only the score or the musicians belong, but also you as an audience, or anyone involved in making this performance possible. It presupposes instruments such as the marimbas, but also the acoustic of the space we are in. In a musical performance the participants follow conventions and habits that often originated long ago.

In his book Musicking, Small gives a thick description of the typical situation in classical music, the symphonic concert in a concert hall. Let's enter the Concertgebouw in Amsterdam as it is today. We leave the noisy street life behind. From the cash desks, we walk to the foyer through corridors decorated with paintings of famous musicians. In the hall itself, the atmosphere of seriousness and history is undeniable. The musical canon is present in the names of great composers - all men - on the walls and balconies. Audience members chat as musicians climb the stairs to the stage, entering from different doors than the listeners. Instruments are tuned. The conductor descends a long stairway to the stage. This entrance ceremony underlines the importance of the maestro, who is the focal point of the artistic responsibility of those on the stage.

\footnotetext{
2 "To music is to take part, in any capacity, in a musical performance, whether by performing, by listening, by rehearsing, or practicing, by providing material for performance (what is called composition), or by dancing. (...) Using the concept of musicking as a human encounter, we can ask the wider and more interesting question: What does it mean that this performance (of this work) takes place at this time, in this place, with these participants? Or to put it more simply, we can ask of the performance, any performance anywhere and at any time, What is really going on here?"'" (Small, C. (1998). Musicking: The Meanings of Performing and Listening. Middletown, CT, Wesleyan University Press, p. 9-10)
} 
Two hands are raised, the silence in the audience deepens, a gesture evokes the beginning of the music. ${ }^{3}$

In the Concertgebouw we do not only listen to music from the past, we participate in a ritual that has a history. When we debate if and why classical music is in crisis, we need to address this "pastness" of the practice. How to shape new futures for an art form that revolves around reiterating the past? I find this a fascinating and important question. To try out possible answers, I will first historically situate the current debates on classical music. Limiting my scope, I will focus on symphonic orchestras and Dutch cultural policies. To rethink what is at stake in changing classical music practices, I will then analyse philosophical concepts of how music can exist as a work of art. Extending this conceptual analysis to research, I will outline some issues and questions that need to be addressed in the project of innovating classical music.

\section{II}

The symphonic practice that Small describes, originated in the nineteenth century. Following the example of museums, musicians and music lovers constructed their own canon around composers such as Ludwig van Beethoven. ${ }^{4}$ Their genius was to write music that broke with conventions to express an inner world of emotions. With the individualization of musical style, it became more important to notate music according to the intentions of the composer. For musicians, being faithful to the 'text' that the composer had written, imposed new demands on their instrumental and vocal skills. Technical virtuosity became an artistic criterion in itself.

The historicity of the romantic art ideal focused on the resurgence of the past as a source of new art, and on the other hand on the creation of art for eternity. Whereas composers before him wrote their music for specific occasions, the later compositions of Beethoven were thought of

\footnotetext{
${ }^{3}$ My description of the symphonic music concert ritual draws on the ethnographic account that Christopher Small gives in his book Musicking (1998).

${ }^{4}$ DeNora, T. (1996). Beethoven and the construction of genius: Musical politics in Vienna, 17921803. Berkely: University of California Press.
} 
as timeless masterworks. As their musical language became more complex, composers developed a sense of progress in their art. ${ }^{5}$ Controversies arose on the direction of progress. Whereas Johannes Brahms held on to conventional forms such as the symphony and the sonata, Franz Liszt and Richard Wagner created new forms of harmonic complexity in their musical language. The quest for expression finally led to the atonal music that Arnold Schönberg wrote after 1908, the year of his Second String Quartet.

Musical romanticism required new instrumental colours and dynamic range. Where Haydn and Mozart used orchestras that did not exceed thirty to forty musicians, the Symphonie Fantastique that Hector Berlioz wrote in 1830 asks for more than a hundred musicians. To synchronise their playing, conductors became more important. As the size of orchestras increased, concert halls became larger. Romantic aesthetic ideas materialized in buildings such as the Concertgebouw in Amsterdam, built in 1888. ${ }^{6}$ Following examples in other European cities, the architect Van Gendt succeeded in creating a space in which music could sound as an isolated object of aesthetic admiration. ${ }^{7}$ Audiences were disciplined to listen silent and attentively. ${ }^{8}$

The emergence of concert halls where the bourgeoisie could focus on serious musical enjoyment coincides with the changing meaning of music in society. In a sociological sense, a separation emerged between art music, which was considered a form of high culture and which requested a degree of cultural upbringing or Bildung to appreciate it, and the music for the everyday life. In the course of the nineteenth century, classical music became an art form that is defined in the romantic order,

\footnotetext{
${ }^{5}$ Rosen, C. (1996). The Romantic Generation. London: HarperCollins Publishers. See also Doorman, M. (2005). Steeds mooier. Over vooruitgang in de kunst. Amsterdam: Bert Bakker.

6 Cressman, D. (2016). Building musical culture in Nineteenth-century Amsterdam: The Concertgebouw. Amsterdam: Amsterdam University Press.

7 Two decades later, the new science of acoustics was able to explain the success of the building by showing how the shape and volume of the space resulted in a reverberation time that was perfect for large musical ensembles such as the symphony orchestra (Cressman, 2016, p. 82).

8 Johnson, J. H. (1994). Listening in Paris: A cultural history. Berkeley/Los Angeles/London: University of California Press. See also Smithuijsen, C. (2001). Een verbazende stilte: klassieke muziek, gedragsregels en sociale controle in de concertzaal. Amsterdam: Boekmanstudies.
} 
as my colleague Maarten Doorman calls it. ${ }^{9}$ With other art forms, it shared the regulative idea of aesthetic autonomy: the self-regulation of art, independent of traditional morality, religion or politics, which allowed the performing and fine arts to become an independent domain in society. Autonomy thus related to the musical work itself, to the institutions responsible for performing these works, and to the place of art music in society. ${ }^{10}$

\section{III}

Although symphony orchestras continued to perform newly composed music in twentieth century, they increasingly became museums of a symphonic past. The avant-garde in the postwar decades considered them as bourgeois and artistically conservative institutions. Composers like Steve Reich founded their own ensembles of musicians who were committed to new music. In the Netherlands, musicians started collectives such as the Schönberg, the Asko, and the Nieuw Ensemble that specialised in music from the twentieth century. ${ }^{11}$ At the other end of the symphonic orchestra repertoire, early music consorts advocated historically informed performance practices, playing period instruments according to historical techniques. A heterogeneous musical landscape emerged in which symphonic orchestras focused on core repertoire from the late eighteenth to the early twentieth century.

These changes were initially reflected in the funding of music organisations, favoring new developments and questioning the hegemony of the orchestras. Since the Second World War, the Dutch government supported a musical infrastructure that was able to perform a broad repertoire of art music. This changed after the economic crisis in the 1980s. Neoliberal policies questioned the role of the government as

\footnotetext{
${ }^{9}$ Doorman, M. (2004). De romantische orde. Amsterdam: Uitgeverij Bert Bakker.

${ }^{10}$ I want to thank Frank Mineur for what I learned from him about the relations between art, autonomy, and the public sphere.

${ }^{11}$ For a history of Dutch musical life in the twentieth century, see Oskamp, J. (2016). Een behoorlijk kabaal. Een cultuurgeschiedenis van Nederland in de twintigste eeuw. Amsterdam: Ambo/Anthos. See also Adlington, R. (2013). Composing dissent: avant-garde music in 1960s Amsterdam. Oxford: Oxford University Press.
} 
the main funder of cultural institutions. A long series of budget cuts began and in the decades that followed, symphonic orchestras in the Netherlands merged or ceased to exist. ${ }^{12}$ Today's market imperative introduces a paradox of legitimation: orchestras and ensembles need to be funded because they are important, but if they are so important, why are there not enough people prepared to pay the full price of their tickets? ${ }^{13}$

To explain the paradox, new narratives on the declining relevance of classical music and its exemplary institution the symphony orchestra emerged. ${ }^{14}$ These focus on audiences. Social-demographic developments such as an aging population, and immigration of people who value different musical canons affect the composition of audiences. ${ }^{15}$ In an experience society ${ }^{16}$, people have different expectations about their engagement with classical music. Its identification with high culture is no longer valued, especially among young people. In the age of YouTube and Spotify, people's connections to classical music are said to be too ephemeral to justify the long-term investment in time and passion that characterizes its amateurs. ${ }^{17}$ The canon of musical works, including those created by the avant-garde in the twentieth century, has lost its authority for many people.

Nowadays, Dutch musical organisations including symphony orchestras only receive funding if they cope with the changes in

\footnotetext{
12 After the most recent round of cuts, in 2011, many of the ensembles for early and new music saw their subsidies sharply reduced or even terminated.

${ }^{13}$ Veerle Spronck formulated this paradox in her research project Listen Closely: Innovating Participation in Symphonic Music.

14 The decline or even the end of classical music has been announced before. See: Johnson, J. (2002). Who needs classical music? Cultural choice and musical value. Oxford: Oxford University Press, and Kramer, L. (2007). Why classical music still matters. Berkeley/Los Angeles/ London: University of California Press.

${ }_{15}$ Ministerie van Onderwijs, Cultuur en Wetenschap. (2014). Cultuur in beeld 2014. Den Haag: Ministerie van OCW.

16 See Schulze, G. (1993). Die Erlebnisgesellschaft: Kultursoziologie der Gegenwart. Frankfurt/New York: Campus Verlag.

17 Baricco, A. (2011). De barbaren. Amsterdam: Uitgeverij De Bezige Bij. See also Ruth Finnegan's ground breaking study on amateur music making in the English town of Milton Keynes. (Finnegan, R. (1989). The hidden musicians: Music-making in an English town. Cambridge: Cambridge University Press.)
} 
composition, preferences, and behaviour of their audiences. ${ }^{18}$ Where the government reduces funding, artists and arts institutions have to become cultural entrepreneurs. In a 2011 cultural policy paper, artists are invited to write a "business plan" that provides information about the "stakeholders", a healthy "financing mix", and a sustainable "revenue model". A central goal is "attracting new target groups". ${ }^{19}$ In a more recent policy papers the market discourse figures less prominently, but the "connection with a changing society" remains a central criterion. ${ }^{20}$

In response to narratives of endings, we see new beginnings. Symphony orchestras and music ensembles critically reevaluate and innovate their practices. Some orchestras move out of the concert hall to engage with local communities or play music in class rooms. ${ }^{21}$ The South Netherlands Philharmonic performed in a refurbished industrial building where audience members were invited to literally feel the vibrations of Beethoven's Fourth Symphony in their heads and spines. ${ }^{22}$ Other orchestras include visual or theatrical elements during their concerts, such as video images that respond to the live music. Concertgoers are

${ }^{18}$ For an overview of these changes, see Raad voor Cultuur. (2014). De Cultuurverkenning. Ontwikkelingen en trends in het culturele leven in Nederland. Den Haag: Raad voor Cultuur, pp. 41-43.

${ }^{19}$ Ministerie van Onderwijs, Cultuur en Wetenschap. (2011). Meer dan kwaliteit. Een nieuwe visie op cultuurbeleid. Den Haag: Ministerie van OCW, p. 37.

${ }^{20}$ Ministerie van Onderwijs, Cultuur en Wetenschap. (2013). Cultuur beweegt. De betekenis van cultuur in een veranderende samenleving. Den Haag: Ministerie van OCW, p. 1.

${ }^{21}$ An example is The Deutsche Kammerphilharmonie Bremen which located its rehearsal rooms in the building of the Bremen-Ost comprehensive school in the heart of a socially challenged area of the city. In this Future Lab, The Deutsche Kammerphilharmonie Bremen promotes engagement with the entire community through new and effective ways of communicating classical music. The orchestra interacts with the school in numerous projects. In the Future Lab, The Deutsche Kammerphilharmonie Bremen also initiates encounters with people of differing social and cultural backgrounds. This commitment was recognized in 2009 by Germany's Minister of State for Culture, Bernd Neumann, as a nationwide pilot project in the area of cultural education.

22 This example refers to concerts in 2018 in the i-Classics series of the South Netherlands Philharmonic. Together with tech company CREW and sound artist Christoph De Boeck, the orchestra collaborated to create a new spatial and bodily experience of Beethoven's Fourth Symphony. To create a continuous experience, new connecting compositions, Interlude I \& II, were written by Jesse Passenier, to link between the movements of Beethoven's Symphony. Disruption, enrichment, and adaptation were key principles in this technological experiment. The production was led by conductor Kristiina Poska. Source: (n.d.) iClassics Music E Technology. Retrieved March 1st, 2019, from https://jessepassenier.com/iclassics/ 
encouraged to read about the music they hear in real time on their smartphones with apps such as Wolfgang. ${ }^{23}$ Concerts are streamed live through what the Berlin Philharmonic has called the digital concert hall "where we play just for you", to quote the website. ${ }^{24}$ Orchestras such as the Dutch Pynarello break with concert conventions by performing without scores. ${ }^{25}$ The concerts of the Manchester Collective reflect a diverse musical landscape where "The only thing we ask of you [...] is that you listen. Really listen." 26 Ensemble Modern gives the audience a role as artist in the concert process. Their aim is to re-explore the relationship between composer, musician and audience and to enable the audience to participate. ${ }^{27}$

The cultural policies that I summarized led to debates. And so have the experiments and innovations of which I gave examples. Some fear that the market imperative and its focus on the cultural entrepreneur will lead to an erosion of artistic quality, or an endless repetition of wellknown music. Musicians who studied for years to learn their craft, wonder what new roles they have in innovative concert formats. Others argue that participatory music projects risk giving up the critical potential of the arts in society. They contrast instrumentalized art to an art that is autonomous enough to question the societal status quo. ${ }^{28}$

All this reveals an irony. Attempts to innovate classical music practice only seem to expose its roots in the romantic order. What is at stake are the value of timeless musical works and the skills to perform them, as well as the position of orchestras and ensembles as relatively

\footnotetext{
23 Source: (n.d.). Wolfgang. Ontdek wat je hoort. Retrieved March 1st, 2011, from: http://wolfgangapp.nl/.

${ }^{24}$ Source: (n.d.). Digital concert hall. Where we play just for you. Retrieved March 1st, 2011, from: https://www.digitalconcerthall.com/en/home.

25 Source: (n.d.). Pynarello. Doe mee!. Retrieved March 1st, 2011, from: https://www.pynarello.com/.

${ }^{26}$ Source: (n.d.). Manchester Collective. Radical Radical human experiences through live music. Retrieved March 1st, 2011, from: https:/ / manchestercollective.co.uk/bio.

27 Source: (n.d.). Connect. The audience as artist. Retrieved March 1st, 2011, from: https:/ / www.ensemble-modern.com/de/projekte/aktuell/connect-2016.

${ }_{28}$ This argument has been developed by Claire Bishop in her book Artificial Hells. (Bishop, C. (2012). Artificial Hells. Participatory Art and the Politics of Spectatorship. London: Verso.). See also Gabriëls (2017) who speaks of the 'participatory imperative'. (Gabriëls, R. (2017). Het imperatief van de participatie. Over kunst, engagement en onderwijs. Kunstzone, 2017(5), 20-23.).
} 
autonomous art institutions. This brings me back to the question I formulated earlier: how to shape new futures for an art form that revolves around reiterating the past? Or to put it differently, how to rethink the "pastness" in and of the practice? To answer these questions, we need to delve into philosophical reflections on how music can exist as a work of art.

\section{IV}

In everyday life, we do not ask questions about musical works. We buy a ticket for Mahler Five, or we listen to the Second Symphony of Rachmaninov at home. For philosophers, however, the concept of a musical work presents a puzzle. ${ }^{29}$ To understand why, let's go back to the music before this lecture. If you listened to the music, but did not know it was composed by Steve Reich, did you listen to a musical work? And if you recognized the music as Nagoya Marimbas, is the performance today identical with the work that has that name? Or should we say that the work is represented by the notes in the score? But Reich wrote the score in such a way that the performance can last five minutes, or also ten. Are we then still talking about one musical work or many? As the author, Reich has the copyright of the score, so isn't that reason enough to believe that he created a musical work? Just how then does Nagoya Marimbas exist?

In her book The Imaginary Museum of Musical Works (1994), Lydia Goehr approaches this question in two steps. ${ }^{30}$ She first critically discusses the attempts of philosophers such as Nelson Goodman and Jerrold Levinson to describe and define the mode of existence of musical works. She shows how any fixed definition has to establish a set of either essential properties or identity conditions. ${ }^{31}$ This approach, she argues,

\footnotetext{
${ }^{29}$ In this lecture, I can only hint at the complexity of this puzzle. For an overview of the philosophy of performable works, see Davies, D. (2011). Philosophy of the Performing Arts. Chicester: Wiley-Blackwell. and Davies, S. (2001). Musical works and performances: A philosophical exploration. Oxford: Clarendon Press.

${ }^{30}$ I want to thank my colleague Darryl Cressman for pointing out this book to me.

31 Goehr, L. (1992). The Imaginary Museum of Musical Works: An Essay in the Philosophy of Music: An Essay in the Philosophy of Music. Oxford: Oxford University Press, p. 72.
} 
does not take into account the historical, contingent, and possibly changing character of these properties and conditions. Goehr suggests that instead of describing what kind of object a musical work is, we should study how the concept of a work emerged in classical music and how it has functioned therein. ${ }^{32}$ Her strategy is to trade thought experiments in music ontology for historical research. Drawing on archival sources, she shows how the idea of the stable musical work only emerged around 1800. In what Goehr calls the Beethoven paradigm, it regulated how composers notated their music, how performers were expected to be true to the score to give authentic performances, and how audiences listened in silence to hear the beauty of the work itself. ${ }^{33}$

We can now see how the musical work concept is at the heart of the romantic order in classical music. It helps to understand the "pastness" of this practice in two ways. It explains how music can be transmitted through time as a relatively stable and autonomous artwork. ${ }^{34}$ And it also reveals the continuities in practice between the past and the present as obduracies that cannot easily be changed.

Yet change is what interests me here. Coming back to the storylines of endings and beginnings that I mentioned earlier - the crisis in classical music practice and the attempts to innovate it - I need to know if there are ways of conceiving the historicity of music other than with the romantic work concept. But first let me ask Axel and Frank to play on their marimbas.

[Performance of Variations 18 and 2 from the Goldberg Variations, BWV 998 by Johann Sebastian Bach]

At first sight, we participated in a traditional concert situation. Axel and Frank performed two of the thirty Goldberg Variations, a musical work published by Johann Sebastian Bach in 1741. To be able to play this

\footnotetext{
32 Ibid. p. 4.

${ }^{33}$ Ibid. pp. 205-243.

34 Although in different ways, consecutive performance styles all aimed at authentic renderings of the work. Bruce Haynes (2007) distinguishes between romantic, modern, and historically informed performance practice. Although very different in their aesthetic ideals, they share the centrality of the work concept. (Haynes, B. (2007). The End of Early Music: A Period Performer's History of Music for the Twenty-First Century. Oxford: Oxford University Press.)
} 
work, they trained their skills for years. And in your listening, you showed that you know the etiquette of the classical music concert. Even if this auditorium is not the Concertgebouw, we enacted the ritual that allows us to experience Bach's music as art. But if one looks more closely, none of this really fits. The notes that Bach wrote down only came to be seen as a musical work through the lens of the romanticism of the nineteenth century. ${ }^{35}$ Bach would probably be very surprised to hear his music on two marimbas, instruments unknown in Europe in his time. ${ }^{36}$ It sounded very different on the harpsichords he knew. And how about you? You listened attentively, but you probably also realize that I am using music to make an argument that you are trying to follow. Listening to it is not our primary goal here.

\section{$\mathrm{V}$}

How then does Bach's music appear among us here? And how do we participate in it? To answer these questions, I will make a philosophical detour to the hermeneutic aesthetics of Hans-Georg Gadamer. ${ }^{37}$ In 1960, he published Truth and Method in which he attempts to regain the concept of truth for the humanities. Our experience of society and history, Gadamer argues, cannot be raised to a science by following the methodological procedures of the natural or the social sciences. A historian does not see a concrete phenomenon as an instance of a

\footnotetext{
35 "Central to the historical thesis is the claim that Bach did not intend to compose musical works. Only by adopting a modern perspective - a perspective foreign to Bach - would we say that he had." (Goehr, L. (1992). The Imaginary Museum of Musical Works: An Essay in the Philosophy of Music: An Essay in the Philosophy of Music. Oxford, Oxford University Press, p. 8.) ${ }^{36}$ For a musician's perspective on playing Bach on marimba, see Schooneboom, M. (2000, February 15). 'Als Bach had geweten dat de marimba bestond...'. Trouw. Retrieved March 3, 2010 from: https://www.trouw.nl/home/-als-bach-had-geweten-dat-de-marimbabestond- a91bc802/.

${ }^{37}$ I want to thank Henk Borgdorff for pointing out to me the Dutch translation of Wahrheit und Methode and encouraging me to read it. My reading of Gadamer is informed by Warnke, G. (2013). Gadamer: Hermeneutics, tradition and reason. Cambridge: Polity Press, Davey, N. (2013). Unfinished Worlds: Hermeneutics, Aesthetics and Gadamer. Edinburgh: Edinburgh University Press, and Thomas, M. J. (2018). Gadamer and the Hermeneutics of Early Music Performance. Research in Phenomenology, 48(3), 365-384.
} 
universal rule. ${ }^{38}$ Rather, she tries to understand how this phenomenon came to happen the way it did in the continued development of a history in which she herself participates. ${ }^{39}$ This type of understanding is an experience of truth that escapes scientific methods, and yet can be legitimated as truth.

As a first step in his argument, Gadamer develops a hermeneutic account of how art exists. He criticizes nineteenth century romantic writers and philosophers such as Johann Gottlieb Fichte and Friedrich Schiller. They argued that art and aesthetic experience are abstract because they derive from a realm of the beautiful that is timeless. The aesthetic experience must focus on the artwork itself, and abstain from non-aesthetical aspects such as goal and function. By disregarding the original context of life, and the religious or secular function that gave it significance, it becomes visible as a pure work of art. Gadamer calls this process of abstraction "aesthetic differentiation". ${ }^{40}$ The aesthetic differentiation also created an external existence of art in places solely dedicated to it such as the universal library, the museum, the theatre, and as we saw the concert hall.

In Gadamer's hermeneutic approach, however, the work of art cannot be isolated from the contingencies of the conditions under which it presents itself. On the contrary. It can only exist in its relations to the lifeworld. The music of Bach we just heard comes from a particular moment and person in history, yet we encounter it here as immediately present. How is this possible? Gadamer's answer is that we have to think

\footnotetext{
38 "However much experiential universals are involved, the aim is not to confirm and extend these universalized experiences in order to attain knowledge of a law-e.g., how men, peoples, and states evolve-but to understand how this man, this people, or this state is what it has become or, more generally, how it happened that it is so." (Gadamer, H.-G. (1989 [1960]). Truth and Method. New York: Continuum, p. 4.)

${ }^{39}$ The German word used here is Überlieferung. The English language does not have a verb of adjective that does justice to the active connotation of this word.

40 "What we call a work of art and experience (erleben) aesthetically depends on a process of abstraction. By disregarding everything in which a work is rooted (its original context of life, and the religious or secular function that gave it significance), it becomes visible as the "pure work of art." In performing this abstraction, aesthetic consciousness performs a task that is positive in itself. It shows what a pure work of art is, and allows it to exist in its own right. I call this "aesthetic differentiation"." (Gadamer, (1989 [1960], p. 74).
} 
of it as a game that is played. ${ }^{41}$ Let's take chess as an example. Any particular game of chess that we play here today does not exist in the subjective experience of the players or the viewers, but in the game itself as a 'subject'. We could say that it plays us. Why? If we play a game, we follow its rules and perform the tasks that it sets. ${ }^{42}$ It is in the performing of the task that a play presents itself. ${ }^{43}$

Gadamer now makes a crucial comparison between play and art. Like games, art can be presented in many ways, yet it has a binding character. The productive variations that result from presenting the artwork under different conditions lead to a tradition to which every new attempt to present it has to relate. In music and theatre, presenting works of art is thus not a matter of following earlier acts of presenting, but of interpretations that keep the future identity and continuity of the artwork open. ${ }^{44}$ Gadamer does not distinguish between an artwork and its presentation. Like chess, it only exists when it is actually played. But how then can we think of a singular work at all? Gadamer's answer is to compare it to a periodic festival like carnival. The upcoming carnival is not a repetition or a remembrance of how carnival was originally celebrated. However far the origin of carnival is from us, in its celebration it exists in the participation of those who are present. ${ }^{45}$

\footnotetext{
${ }^{41}$ This concept also played a role in the aesthetics of both Immanuel Kant and Friedrich Schiller, but Gadamer gives it a different meaning.

42 "This suggests a general characteristic of the nature of play that is reflected in playing: all playing is a being-played. The attraction of a game, the fascination it exerts, consists precisely in the fact that the game masters the players. Even in the case of games in which one tries to perform tasks that one has set oneself, there is a risk that they will not "work," "succeed," or "succeed again," which is the attraction of the game. Whoever "tries" is in fact the one who is tried. The real subject of the game (this is shown in precisely those experiences in which there is only a single player) is not the player but instead the game itself." (Gadamer, (1989 [1960], p. 106.).

43 The German word here is Darstellung. It has many connotations, such as representation, presentation, depiction, description, account, or performance.

44 These interpretations do not give the interpreter unlimited freedom, and on the other hand Gadamer sees canonizations of particular interpretations, e.g. a recording of a musical composition by its composer, as a simple imitation of a model that would deny the real task of interpretation. Interestingly, Gadamer seems to criticize what later became known as the historically informed performance practice movement: "Thus, for example, historicizing presentations - e.g., of music played on old instruments - are not as faithful as they seem. Rather, they are an imitation of an imitation and are thus in danger "of standing at a third remove from the truth" (Plato)." (Gadamer, (1989 [1960], p. 118.).

${ }^{45}$ Gadamer, (1989 [1960]), p. 120.
} 
Artworks also need the participation of those present to their instantiation. In Greek tragedy, the spectator recognizes himself in the actors he sees on the stage. This continuity of meaning is what enables tragedies to exist in the present. Similarly, every work of art has its own world, but this does not mean that when this original world has vanished, it can only exist in an alienated aesthetic consciousness. On the contrary, it exists through its acquiring of new uses and adapting to changed circumstances - this is called mediation. Artistic truth then, results not from our reconstruction of the original goal of a work of art in the world in which it emerged and thus restore its meaning. Rather, it comes from bringing artworks into a "thoughtful mediation with contemporary life". 46

Presenting artworks from the past requires what Gadamer calls a hermeneutical situation. ${ }^{47}$ In this situation we are conscious of the fact that, as interpreters, we are affected by history. ${ }^{48}$ We are not separated from the past, but connected to it through tradition. In everyday language, the word 'tradition' might suggest something that lies behind us, or that is repeated without reflection. For Gadamer it means that the past is actively handed over in our situated understandings and applications of it. It requires active questioning and self-reflection. Gadamer's conception of tradition is dialogical: rather than a form of antiquarianism, it is a continuing debate on questions, problems and issues to which we ourselves contribute. When we play works of art, we revisit the tradition that handed them down to us. Presenting them in our hermeneutical situation will add new meanings, that will in turn expand the tradition. This is why playing works of art is fundamentally

\footnotetext{
${ }^{46}$ Gadamer, (1989 [1960]), p. 161 (emphasis in the original).

47 "We define the concept of "situation" by saying that it represents a standpoint that limits the possibility of vision. Hence essential to the concept of situation is the concept of "horizon." The horizon is the range of vision that includes everything that can be seen from a particular vantage point. Applying this to the thinking mind, we speak of narrowness of horizon, of the possible expansion of horizon, of the opening up of new horizons, and so forth. Since Nietzsche and Husserl, the word has been used in philosophy to characterize the way in which thought is tied to its finite determinacy, and the way one's range of vision is gradually expanded. A person who has no horizon does not see far enough and hence over-values what is nearest to him. On the other hand, "to have a horizon" means not being limited to what is nearby but being able to see beyond." (Gadamer, (1989 [1960], p. 301).

${ }^{48}$ Gadamer uses the term "wirkungsgeschichtliches Bewusstsein". (Ibid. p. 301)
} 
unfinished: their meaning is never exhausted as long as we continue to play them in new situations.

\section{VI}

How does this idea help us to rethink the "pastness" of the practice of classical music? Following Gadamer's ontology of artworks as play, musical works no longer exist as objects that are transmitted through history as relatively stable objects, but as presentations in a hermeneutical situation. If we play Bach's Goldberg Variations on marimbas in this lecture hall, earlier interpretations resonate in how we play them, and at the same time they acquire a new meaning that expands the tradition. As we saw, the stability of the romantic work concept explains why classical music practice is difficult to change. What happens if we see this practice of Western art music through the lens of Gadamer's hermeneutic work concept?

Let's start with the canon of musical works. This is a collection of compositions the aesthetic value of which is uncontested; they are performed to experience this value. A hermeneutical perspective sees a tradition as a continued history of presentations that all bear the traces of the situation in which these presentations took place. If we play a musical composition, we are aware of these former presentations and at the same we bring it into our own situation. Think of a work of architecture like the Concertgebouw. After it was built, it did not stand unchanged between the other buildings. As time passes, the building is adapted to new city life, yet it contains both its history of previous changes and its identity. ${ }^{49}$ If we think of classical music concerts as hermeneutical situations, we are not only reconstructing a past meaning

\footnotetext{
49 "Works of architecture do not stand motionless on the shore of the stream of history, but are borne along by it. Even if historically-minded ages try to reconstruct the architecture of an earlier age, they cannot turn back the wheel of history, but must mediate in a new and better way between the past and the present. Even the restorer or the preserver of ancient monuments remains an artist of his time." (Gadamer, (1989 [1960], p. 185) In this quote, Gadamer elaborates on what Watson (2010), in the different context of pipe organ building and restoration, has called the 'paradox of conservation and restoration'. (Watson, J. R. (2010). Artifacts in use: the paradox of restoration and the conservation of organs. Richmond: OHS Press.)
} 
of the music, but we mediate the music with our own world. The empirical question then is how the hermeneutical situation is organized in practice. This can be the ritual of the classical music concert in the Concertgebouw, but also a multi-sensory performance in a refurbished industrial building.

The romantic order developed criteria such as authenticity and fidelity to the written music as text. A musical performance is good if it is true to the composer's intentions or the written score. ${ }^{50}$ Aesthetic autonomy set norms for judging the composition, its performance, and its reception. It also provided a way to think of the critical role music can have in society. ${ }^{51}$ What normative criteria do we have to judge a musical performance or composition when we see art as play? Gadamer's goal is not to give a theory of art that allows us to distinguish between art and non-art, or between good and bad art. Rather, his hermeneutical aesthetics can help us when we encounter art and contemplate its meaning. We play Bach because the music says something to us. The task of interpreting it, is to see what new possible meanings it can have by mediating it in our own situation. We bring our aesthetic experiences and norms to the hermeneutic situation, but they also result from it. After we play Bach's Goldberg Variations on marimbas we have new arguments why it is so good: because it is flexible enough to exist in very different situations, yet retain its identity. Our encounter with art and music comes with a responsibility. If we want it to exist, we have to hand it over to the future by playing it.

Classical music as it originated in the nineteenth century is based on a division of artistic and reflexive labour. Composers create, musicians perform, audiences listen. Musicologists took up the task of scholarly reflection on music. They analysed scores as representations of musical structures and meanings. Music criticism became the domain of experts who had the knowledge and experience to make value judgments about works and performances. Gadamer's aesthetics provides a less

\footnotetext{
50 See Kivy, P. (1998). Authenticities: Philosophical reflections on musical performance. Ithaca and London, Cornell University Press.

51 Theodor W. Adorno has written extensively about this issue. See Adorno, Th. W. (1970). Ästhetische Theorie. Frankfurt am Main: Surhkamp. See also DeNora, T. (2003). After Adorno. Rethinking Music Sociology. Cambridge: Cambridge University Press.
} 
hierarchical mode of participation. Our encounter with an artwork and its tradition confronts us with the task of presenting it, and this task is shared by practitioners and theoreticians. Playing a musical work requires that all participate in rehearsal, practising, trying it out to see what new understandings it has to offer. Mediating the music with contemporary life implies that we learn, albeit in different ways.

\section{VII}

It is time to revisit the issue of a crisis in classical music. To know what is at stake in the debates on this crisis, we should address the "pastness" of the practice. Analysing the romantic work concept that emerged in the nineteenth century helps us to understand the rituals, habits, conventions, and values of classical music. I have argued that a hermeneutic approach to the musical work enables us to rethink the ways we transmit music through time, that doing so comes with responsibilities, and that playing musical works needs the participation of all involved. How can this approach help to analyse and evaluate the discourse on the innovation of classical music, as wells as practical initiatives to innovate the practice of classical music? Answering this question requires that we study and experiment with musicking as a hermeneutical situation. Let me start with how to study these situations empirically.

For a long time, scholars made a distinction between the study of music as writing and music as practice. Musicologists analysed scores and their histories; sociologists, historians and anthropologists focused on how music works and how its practices evolve. ${ }^{52}$ Recent research has questioned this gap between page and stage, between the musical work itself and the practical work that has to be done to make music happen. ${ }^{53}$ Music in the making is understood here as a social, material, and situated practice. ${ }^{54}$ Examining musical hermeneutics in these situations

\footnotetext{
52 Byrne, D. (2012). How music works. San Francisco: McSweeney's.

${ }^{53}$ Cook, N. (2014). Beyond the Score: Music as Performance. Oxford: Oxford University Press.

${ }_{54}$ For a general account on practice theory, see Schatzki, T., Knorr Cetina, K. \& Von Savigny, E. (Eds.). (2001). The Practice Turn in Contemporary Theory. New York: Routledge. For an overview of the practice turn and after in research on musical cultures, see: Born, G.
} 
of "action" can draw on interdisciplinary practice research. ${ }^{55}$ To give an example, fifteen years ago my colleagues Karin Bijsterveld and Trevor Pinch argued that the field of science and technology studies has much to offer for research on music and sound.56 If we think of musical instruments as technological artefacts, we can study how their meaning and use developed over time in different practices, or how certain aspects were kept stable while others changed. ${ }^{57}$ Coming from a background in the sociology of innovation, Antoine Hennion offers

(2010). For a relational musicology: music and interdisciplinarity, beyond the practice turn: the 2007 Dent Medal Address. Journal of the Royal Musical Association, 135(2), 205-243.

${ }^{55} \mathrm{My}$ use of the term "action" resonates with Bruno Latour's book Science in Action (Latour, B. (1987). Science in action: how to follow scientists and engineers through society. Milton Keynes: Open University Press) and Tia DeNora's book Music-in-Action (DeNora, T. (2016). Music-in-Action. Selected Essays in Sonic Ecology. London: Routledge). See also: Acord, S. K., $\&$ DeNora, T. (2008). Culture and the arts: From art worlds to arts-in-action. The Annals of the American Academy of Political and Social Science, 619(1), 223-237.

56 The field of STS has been growing since the 1960s when it was first established by scientists and engineers who were critical of new techniques emerging from science such as genetic engineering, the growing environmental crisis, and the spread and impact of large scale technological systems such as nuclear power. It now provides a deep understanding of how science, technology, and medicine work internally, as institutions, and as a body of practices that permeate almost all areas of modern life. Scholars in this field study innovations in a variety of contexts, ranging from medicine to transportation. They are interested in how and why certain technologies are successfully adopted and others not. Explanations cannot only be found in the intrinsic properties of a technological artefact. What a technology can do is not only determined by the drawing board of the designer, but also shaped by the way people use it in their everyday practices. For an example related to the use of the Internet, see: Wyatt, S. M. (2003). Non-users also matter: The construction of users and non-users of the Internet. In N. Oudshoorn \& T. Pinch (Eds.), How Users Matter: The Co-Construction of Users and Technology (pp. 67-79). Harvard: MIT Press.

${ }^{57}$ See Pinch, T. and K. Bijsterveld (2004). Sound studies: New technologies and music. Social Studies of Science 34(5): 635-648. Examples of research on innovation of musical instruments are: Bijsterveld, K. and M. Schulp (2004). Breaking into a World of Perfection Innovation in Today's Classical Musical Instruments. Social Studies of Science 34(5): 649-674; Bijsterveld, K. and P.F. Peters (2010). Composing Claims on Musical Instrument Development: A Science and Technology Studies' Contribution. Interdisciplinary Science Reviews 35(2): 106-121; and Pinch, T. and K. Bijsterveld. (2015). Instruments and Innovation. In: J. Sheperd and K. Devine (Eds.), The Routledge Reader on the Sociology of Music (pp. 301-308). London and New York: Routledge. In his book on the Moog synthesizer, Trevor Pinch explains why contemporary synthesizers have interfaces that use conventional keyboards. One of the synthesizer pioneers, Robert Moog, decided that this familiar interface would make it easier for musicians to actually use the new device (Pinch, T. and F. Trocco (2009). Analog days: The invention and impact of the Moog synthesizer. Harvard: Harvard University Press. For an overview of work in the field of sound studies, see Pinch, T., \& Bijsterveld, K. (2012). The Oxford handbook of sound studies. Oxford: Oxford University Press. 
another example in his argument that music from the past can only appear among us here through a collective process of assembling mediators such as musical instruments, scores, norms, languages, institutions, interpreters, and teachers. As ethnographers of musical practices, we can traverse these assemblages. ${ }^{58}$

Handing over musical works in a tradition, as Gadamer describes it, requires practical work that we can study empirically. ${ }^{59}$ But if we stopped here, we would miss a crucial element in his argument, namely that we participate in the tradition that is the object of our study. Music as a matter that concerns us, must be arranged, interpreted, rehearsed, worked upon, listened to, put to the test. ${ }^{60}$ In our understanding of it, knowing and making go hand in hand. In musical practice, this insight is not new of course. To create new works, musicians and composers have always reworked and adapted existing music, studied sources, or the contexts in which they were written, and developed new skills and technologies. Recently, however, the emerging field of artistic research

\footnotetext{
58 In The Passion for Music (2015), Antoine Hennion radically refutes the idea of a musical object "in itself". In his pragmatic analysis, Hennion step by step dismantles the dualism between the aesthetic analysis of the musical work as an isolated art object and the social analysis of the conditions through which it exists. Hennion argues that, instead, the focus should be on the myriad of mediators that are assembled in the collective process of making music appear among us: "(..) all we see are instruments, scores, media, languages, institutions, interpreters and teachers." (Hennion, A. (2015). The Passion for Music: A Sociology of Mediation (M. Rigaud \& P. Collier, Trans.). Surrey, UK: Ashgate, p. 3). If music as an art can only exist through the accumulation of mediators, Hennion argues, then to study music as a practice is to trace the mediations relevant to what we want to understand.

${ }^{59}$ I can only briefly outline here how the study of musical hermeneutics in action could benefit from recent social-scientific research on musical practices. If we think of playing musical works as bringing them into a "thoughtful mediation with contemporary life", this research explores all the practical work that is necessary for this mediation.

${ }^{60}$ I refer here to how Bruno Latour's use of the term 'putting to the test' in his explanation of what he calls 'matters of concern': "A matter of concern is what happens to a matter of fact when you add to it its whole scenography, much like you would do by shifting your attention from the stage to the whole machinery of a theatre. (...) Instead of simply being there, matters of fact begin to look different, to render a different sound, they start to move in all directions, they overflow their boundaries, they include a complete set of new actors, they reveal the fragile envelopes in which they are housed. Instead of "being there whether you like it or not" they still have to be, yes (this is one of the huge differences), they have to be liked, appreciated, tasted, experimented upon, prepared, put to the test." Latour, B. (2008). What Is the Style of Matters of Concern? Two Lectures in Empirical Philosophy. Assen: Van Gorcum, p. 39.
} 
has made this work more explicit. ${ }^{61}$ Some artists present their art not only as works or performances that are acknowledged and evaluated in art worlds. ${ }^{62}$ They also document the research that their art making requires in ways that allow academic communities to assess its epistemic value. They thus expand the ways in which their art works can exist and be made relevant. ${ }^{63}$ Artistic research in music shows how we can think of hermeneutical situations as experiments. Setting up these experimental situations combines reflection and creation. ${ }^{64}$

How can we make this more concrete? Let us return to the issue of audience participation in classical music concerts. To study empirically how audiences engage in music performances, we can draw on the field of audience research in the performing arts. ${ }^{65} \mathrm{We}$ can do ethnographic

${ }^{61}$ Artistic research, or practice-based research in art and design, has gained currency since the 1990s in higher arts education. Artist-scholars in this field focus on the knowledge, understanding and experiences enacted in creative processes and embodied in artistic products such as art works, compositions, and performances.

62 Artistic research is contested, both in the art world and in academia, because it undermines the modernist dichotomy of autonomy and instrumentalism. The debate on art as research deals with fundamental philosophical questions of epistemology and methodology and issues of artistic agency and autonomy, as well as institutional and educational strategies. Publications that map the debate on artistic research or take positions in it are: Hannula, M., Suoranta, J. \& Vadén, T. (2005). Artistic research: theories, methods and practices. Helsinki: Academy of Fine Arts Helsinki; Biggs, M. \& Karlsson, H. (Eds.). (2010). The Routledge companion to research in the arts. New York: Routledge; Wesseling, J. (2011). See it again, say it again: the artist as researcher. Amsterdam: Valiz; Borgdorff, H. (2012). The Conflict of the Faculties: Perspectives on Artistic Research in Academia. Leiden: Leiden University Press; Dombois, F., Bauer, U.M., Mareis, C. \& Schwab, M. (Eds.). (2012). Intellectual birdhouse. Artistic practice as research. London: Koenig; Schwab, M. \& Borgdorff, H. (Eds.). (2014). The exposition of artistic research: publishing in art and academia. Leiden: Leiden University Press, and Benschop, R. (2015). De eland is eigenwijs dier: Een gedachtenexperiment over praktijk en relevantie van artistiek onderzoek. Maastricht: Lectoraat Autonomie en Openbaarheid in de Kunsten: Zuyd University of Applied Sciences.

${ }^{63}$ See also Peters, P.F. (2012). Woorden van hout. Voorbij het dualisme van theorie en praktijk in het kunstvakonderwijs. In: H. Borgdorff en P. Sonderen (Eds.). Denken in kunst. Theorie en reflectie in het kunstonderwijs (pp. 74-85). Leiden: Leiden Publications.

${ }^{64}$ An example is the work done by Paulo de Assis at the Orpheus Institute in Ghent, Belgium. What a musical work is, is in no way limited to the written score and its tradition, De Assis argues. Instead, creativity is propelled by research and imagination leading to a new image of musical works whose performances are not fixed according to a ritual, but as an experimental situation. See: Assis, P. de. (2018). Logic of Experimentation: Rethinking Music Performance through Artistic Research (Orpheus Institute Series). Leuven: Leuven University Press.

${ }^{65}$ For an overview of research in this field, see Burland, K., \& Pitts, S. (2016). Coughing and clapping: Investigating audience experience. London/New York: Routledge. See also: Pitts, S. 
research on how orchestra's experiment with new formats aimed at audience participation. Innovating audience participation through research, however, also requires setting up experimental situations in practice. These could be inspired by experiments in participation in other domains such as science, politics, or health care. ${ }^{66}$ Here, roles and expertise are not assumed, but experiments are designed to let roles and expertise emerge that are normally not recognized as such. ${ }^{67}$ What would change if instead of consumers, listeners and amateurs, symphonic audience members could be citizens, makers, or experts? ${ }^{68}$

E. (2005). What Makes an Audience? Investigating the Roles and Experiences of Listeners at a Chamber Music Festival. Music and Letters, 86(2), 257-269, and Pitts, S. E., Dobson, M. C., Gee, K., \& Spencer, C. P. (2013). Views of an audience: Understanding the orchestral concert experience from player and listener perspectives. Participations, 10(2), 65-95.

${ }_{66}$ Op precies hetzelfde moment dat ik deze oratie uitspreek, op 29 maart 2019 om 16:30, doet prof. dr. Dike van de Mheen dat ook aan the Universiteit Tilburg. Haar oratie gaat in op praktijken van co-creatie tussen wetenschap en samenleving in de zorg en welzijn.

67 For an overview, see Lezaun, J., Marres, N., \& Tironi, M. (2016). Experiments in Participation. In: U. Felt, R. Fouché, C. A. Miller, \& L. Smith-Doer (Eds.), The Handbook of Science and Technology Studies (Fourth Edition, pp. 195-221). Cambridge, Massachusetts; London, England: The MIT Press. Other recent work on participatory experiments as a social science method include: Marres, N. (2012). The experiment in living. In: C. Lury and N. Wakeford (Eds.). Inventive Methods: The Happening of the Social (pp. 76-95). London: Routledge, and Marres, N., Guggenheim, M. \& Wilkie, A. (2018). Inventing the Social. Manchester: Mattering Press. For experiments in arts practices, see Salter, C., Burri, R. V., \& Dumit, J. (2016). Art, Design, and Performance. In: U. Felt, R. Fouché, C. A. Miller, \& L. Smith-Doer (Eds.), The Handbook of Science and Technology Studies (Fourth Edition, pp. 139167). Cambridge, Massachusetts; London, England: The MIT Press.

68 This question summarizes the research problem in the NWO/SIA funded project Artful Participation. Doing Artistic Research with Symphonic Music Audiences (2017-2020) in which Maastricht University, Zuyd Hogeschool, and the South Netherlands Philharmonic collaborate. In this project, the world of the symphony orchestra is studied as an exemplary case in scientific and artistic research on cultural reproduction in the 21st century. The project starts from the assumption that innovation of symphonic music practice is not possible without improving the quality of audience participation in this practice. It combines strategic research into reasons for the declining interest in symphonic music with artistic research to innovate this practice in an artistically relevant way. This artistic research takes place in three experiments with new forms of audience participation. In the current symphonic practice, audiences are performed as listener, consumer or amateur. We will experiment with the new roles of maker, citizen and expert, thus actively involving audiences in programming, making and assessing symphonic music. The reflection on these experiments will result in a learning model that will help to innovate the classical music practice. 
Research on new forms of audience participation is one of the projects in the Maastricht Centre for the Innovation of Classical Music. ${ }^{69}$ The MCICM is a collaboration between the South Netherlands Philharmonic, Maastricht University and the Arts Faculty of Zuyd Hogeschool. The orchestra becomes a place where academic research is tried out, and new problems are found. This research cannot be done without the higher arts education institutes in Maastricht that prepare artists and musicians for their future practice. As a local network, we want to learn from and connect with the work that is done by our colleagues in orchestras, higher arts education institutes, and universities in other places: in Leiden and the Hague, Amsterdam, Rotterdam, Groningen, Utrecht, and Arnhem. And in Ghent, Sheffield, York, London, Linz, Vienna, Berlin, and Paris. It is through this collaboration that, as a centre, we hope to contribute to analysing and shaping classical music futures.

So here we are. I started my lecture by drawing your attention to what the music of Steve Reich did in this auditorium. It gave me a way to introduce the typical situation in classical music, the symphonic music concert, and its challenges. To reflect on these challenges, I contrasted the romantic work concept to Gadamer's idea of comparing musical works to play. Playing Bach on marimbas in this place and moment is what needs to be done to bring the music into existence and hand it down. This is what I talk about when I talk about classical music as work: practising ${ }^{70}$, listening and experimenting ${ }^{71}$, building and restoring

69 The initiative for the MCICM was taken by Stefan Rosu as director of the South Netherlands Philharmonic. To make the symphony orchestra relevant to society in new ways, he argued, research is needed. He proposed a collaboration with Maastricht University. Like an academic hospital, the orchestra could be a place where insights and ideas are tried out, and new problems are found. As the institutions where the skills and expertise of making music and art are practiced and handed over, it is essential that the Conservatorium Maastricht joined the MCICM. The research centre Arts, Autonomy and the Public Sphere at Zuyd University does research that contributes to the strengthening of arts education and practice, and plays a central role in the MCICM through developing new methods and vocabularies to mediate between academic and arts practice-based research.

${ }^{70}$ See Cervino, A., Lettberg, M., \& Lisboa, T. (2011). The Practice of Practising. Leuven: Universitaire Pers Leuven.

${ }^{71}$ See Benschop, R. (2009). Experimenting the listener. Sound art and the doing - done to audience. Krisis, 2009(1), 33-45. For an overview of scholarly on listening in the $19^{\text {th }}$ and $20^{\text {th }}$ 
musical instruments72, studying, reading and writing, criticizing, thinking, wondering, composing and recomposing, rehearsing and discussing afterwards, valuing ${ }^{73}$, performing, and rehearsing again. Innovation of classical music puts this work centre stage. If I think about the archetypal situation of where the work is done, it is not primarily the concert, but the rehearsal. When we seek the relevance of classical music today only in preserving a canon of great symphonies, we risk to forget that their value lies in our living with them. After the concert, there is always the next rehearsal because good symphonies remain unfinished.

century, see: Thorau, C., \& Ziemer, H. (Eds.). (2018). The Oxford Handbook of Music Listening in the 19th and 20th Centuries. Oxford: Oxford University Press. For an anthropological approach of listening, see Becker, J. (2011). Exploring the Habitus of Listening. Anthropological Perspectives. In: Juslin, P.N. and Sloboda, J. (Eds.). Handbook of Music and Emotion: Theory, Research, Applications. Oxford: Oxford University Press, 126-166. I want to thank Linnea Semmerling for pointing out this concept to me.

72 An example is the practice is pipe organ building and restoration. For a exemplary project in which organ research and organ building went hand in hand, see Speerstra, J. (Ed.) (2003). The North German Organ Research Project at Göteborg University. Göteborg: The Göteborg Organ Art Center.

${ }_{73}$ Pitts, S. (2005). Valuing musical participation. Aldershot: Ashgate Publishing Company. See also: Heuts, F., \& Mol, A. (2013). What is a good tomato? A case of valuing in practice. Valuation Studies, 1(2), 125-146. 


\section{Dankwoord}

At the end of my lecture, I would like to say some thank-yous and I will switch between English and Dutch.

De bijzondere leerstoel die ik nu bekleed zou er niet zijn zonder het initiatief van Stefan Rosu. Beste Stefan, je kwam naar onze universiteit met het idee dat je orkest een laboratorium zou kunnen zijn. Op cruciale momenten overtuigde je anderen van het belang van gezamenlijk onderzoek naar vernieuwing van klassieke muziek. Sophie Vanhoonacker stelde als decaan van de Faculteit der Cultuur- en Maatschappijwetenschappen de goede vragen om ons plan sterker te maken. Ik dank het College van Bestuur van de Universiteit Maastricht, in het bijzonder Martin Paul, en het Faculteitsbestuur voor het vertrouwen en de steun. Ik wil ook het College van Bestuur van Zuyd Hogeschool danken voor de bijdrage aan de leerstoel. De Provincie Limburg dank ik dat zij het MCICM mogelijk heeft willen maken

Dat ik hier sta, dank ik aan wat ik heb kunnen leren over wetenschap en over muziek. Tijdens mijn studie in Groningen toonden de colleges van Gerard de Vries mij hoe filosofie orde kan scheppen in de onoverzichtelijkheid van sociologische theorieën. Beste Gerard, dankzij jouw uitnodiging om als promovendus naar Maastricht te komen heb ik mij als wetenschapper kunnen ontwikkelen. Als decaan van onze faculteit schreef Rein de Wilde vijftien jaar geleden een vooruitziend plan om bruggen te bouwen tussen universitair en kunstonderwijs, tussen creatie en reflectie. Beste Rein, veel van wat ik in de afgelopen jaren heb gedaan is geïnspireerd door dat streven en was mogelijk door de kansen die jij mij gaf.

Mijn eerste noten speelde ik op een blokfluit in de vijfde klas. In meester Jansen dank ik mijn piano- en orgelleraren. Als muziekjournalist in Amsterdam maakte Frans de Ruiter mij wegwijs in de muziekwereld en later in het artistiek onderzoek. Dank daarvoor. In de afgelopen vijf jaar was ik vaak in het Orgelpark in Amsterdam. Het Utopa Barokorgel dat daar is gebouwd, toont hoe je het verleden kunt hernemen om de muziek van de toekomst voor te bereiden. Sylvia de Munck, Loek Dijkman, Hans Fidom, Johan Luijmes en Hans Elbertse, dank voor onze 
studiereizen naar de orgels van Zacharias Hildebrandt en voor het kunnen volgen van jullie werk. Mijn muziekvrienden uit Maastricht en elders wil ik danken voor wat ik met jullie leerde tijdens onze repetities en concerten.

I want to thank all my colleagues at the Faculty of Arts and Social Sciences for being the most inspiring and committed academic community I can imagine. I am grateful to work with some of you on art as research. Thanks to my colleagues in the Philosophy Department for what we are: a group of opinionated and generous individuals. Voor hun steun en expertise wil ik mijn collega's van het secretariaat en het Faculteitsbureau bedanken. Mijn collega's van universiteiten en hogescholen uit andere steden dank ik voor onze samenwerking.

I am glad to be back at the Arts Faculty Maastricht and meet old and new colleagues. When I park my bicycle in front of the Conservatory building, I hear the sound of practising students, and it always makes me smile. Getting to know the staff and musicians of the South Netherlands Philharmonic is one of the pleasures of my new job. I am grateful for your hospitality and willingness to let us work with you.

Denise Petzold, Imogen Eve, Karoly Galindo Molina, Neil Smith, Ties van de Werff, and Veerle Spronck have started their research in the MCICM. I am incredibly proud of your work and thankful that we are becoming a team. Zonder de aandachtige inzet van Ruth Benschop waren dat team en het MCICM er niet geweest. We werken al heel lang samen en leren steeds weer bij met elkaar.

Familie en vrienden, uit Maastricht en uit de rest van het land, dank dat jullie hier zijn en voor jullie vriendschap, vaak al zo lang. Hans en Eric Jan, dankzij jullie weet ik hoe bijzonder het is om broers te zijn. Met mijn schoonvader Hans schaak ik en we delen nu ook de toga. Zo'n toga is voor jou heel vertrouwd, ik moet er nog aan wennen. Mijn moeder is niet hier, maar van muziek geniet ze nog net zo als vroeger. Lieve Stijn, je bent meer dan ik kan zeggen, maar het mooist is om samen muziek te maken. En lieve Bernike, ik bewonder je kunst om met nieuwe plannen ons leven telkens een andere wending te geven.

Ik heb gezegd. 


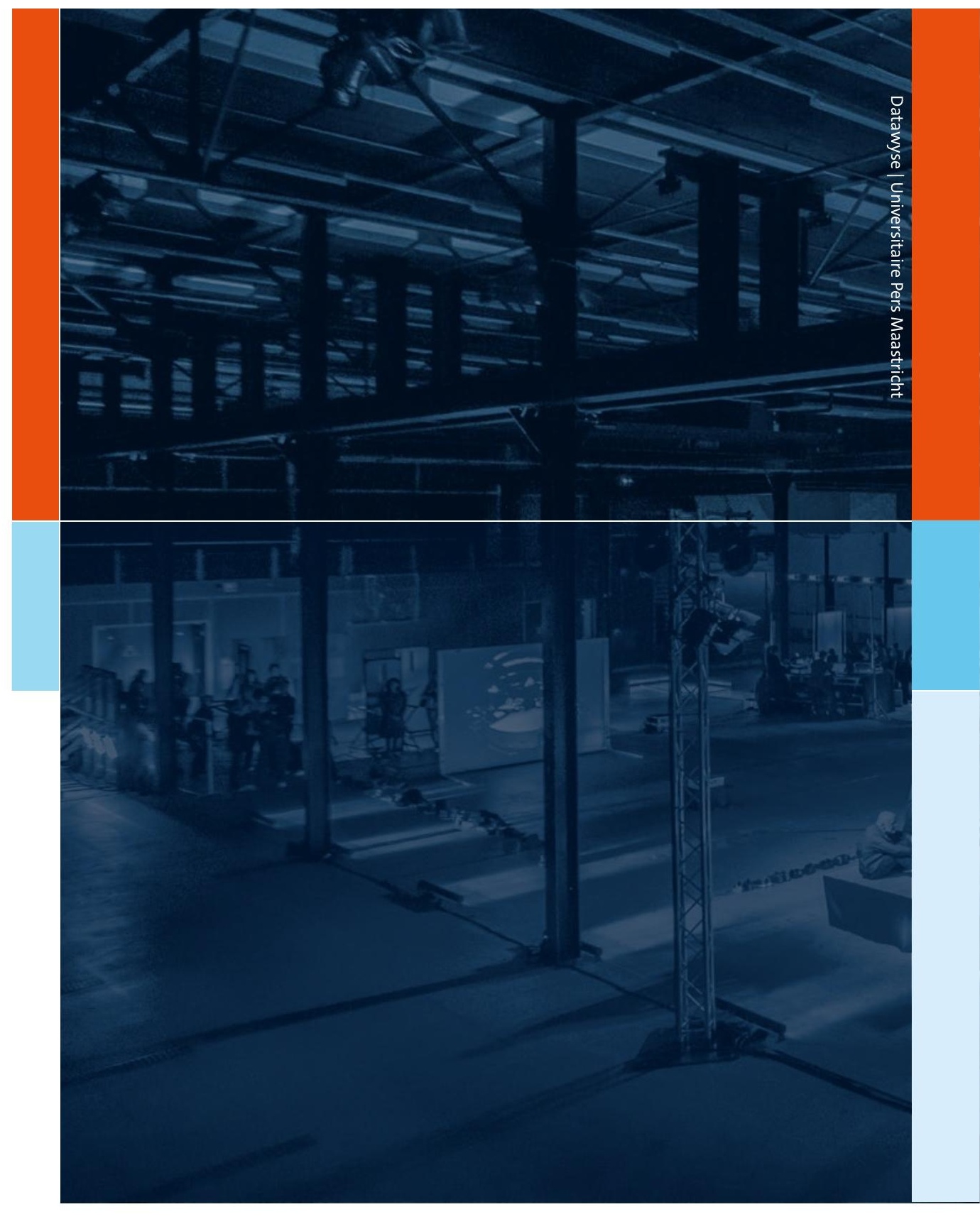

